\title{
Boosting Indonesian Students' Character with Imaginative Literature
}

\author{
Wiwin Widyawati ${ }^{1}$ \\ ${ }^{1}$ STAIN Ponorogo \\ Email : widyawatiwinwin@ymail.com
}

\begin{abstract}
Literature, especially imaginative ones has a purpose to amuse and move the feeling of the readers. More than that, actually imaginative literature also has the potentiality to keep and develop human characteristics. In this globalization era, many students need guidance in developing their motivation and politeness. One of many factors which influence the quality of English education program is the attention and big support of teacher and parents towards the children's need. Therefore, parents and teachers hold the strong role in handling and conducting the children education. In this chance both the parents and the teachers can use the moral values of imaginative literature as a valuable approach in assisting the development of students' characteristics. Without the support from parents and teachers, moral values of imaginative literature cannot be transferred easily. This study aimed at revealing how imaginative literature build students behavior. This research is a descriptive qualitative study which explore the advantages of using imaginative literature as a media to motivate the students in improving the character. Indonesian culture and English culture, has many similarities in some way, principally. The results show that first, there is a very tight relationship between teachers and parents role and moral values of imaginative literature transferring. Second, habit and custom are part of culture which should be cared well to make imaginative literature products become more potential.
\end{abstract}

Keywords: imaginative literature; students; character; education

\section{INTRODUCTION}

Teaching is regarded as the process of assisting individuals to acquire skills, knowledge, and qualities requisite to a good personality, all of which are needed to face life problems, technology and chance in the modern age. As one of those teachings, English literature instructions also supports these goals. English imaginative literature teaching help to improve and develops the student's senses, reasoning ability, attitudes, social and religious understanding, values, and thought processes useful to life in society. This will help the students grow to become a mature member of society as both English literature and English literary sources also give some contributions to the revelations of human values, from which he can draw lesson for his own life [1].

In other words, literature teaching also indirectly gives some good guidance to the students as literature is also a means of transformation that is to lead the wrong back to the right path. The student is guided to select good lessons English 
imaginative literature works, their writers, their critics, etc through his experiences while reading, discussing, analyzing, and giving the appreciation.

Literature help us to be realistic, mature, wise, and human. It helps us understand human sentiments, human interests, human problem, human values, etc. Our lives becomes more tolerant, more balanced, and fuller. We are able to sympathize with others' sufferings. We admire their endurance, perseverance, and their remarkable motivations. We learn to appreciate what others appreciate properly. In this way our capacity for feeling and appreciation increases, and so does our capacity for enjoyment. We become richer through our literary experience.

Related to the existence of literature works and literature teaching, the writer has intention to send some ideas on collaborating among those literary materials, little touch of local philosophy, and student's character building. In an already busy school day, finding time for building character in schools and students can be a challenge. However, school is the first social structure the child encounters, and it provides an excellent opportunity for character-building.

School is not just about learning concepts; it is also a place where a foundation can be built for becoming upstanding adults. Every school should set a tone of respect, honesty and genuine kindness for all students. Whether they like it or not, teachers are role models for students and can provide examples of good character every day in the classroom. Students notice what teachers, do, say, tolerate, and how they handle challenges.

However, character building can also be done proactively through planned actions and activities within the classroom. These classroom activities will encourage students to develop and adopt quality ethical principles and behaviors that can last far beyond the classroom.

\section{METHOD}

This research is a descriptive qualitative study which explore the advantages of using imaginative literature as a media to motivate the students in improving the character. This paper investigated how imaginative literatures appear in students' daily characters, especially when they are in teaching learning process. The data taken from imaginative literature forms or products such as short stories, poems, novels, and local sayings. The further analysis used some theories explaining about the influence of imaginative literature to what the student's behavior.

\section{LOCAL KNOWLEDGE AND IMAGINATIVE LITERATURE}

Local knowledge is part of literature products which also has a great contribution in supporting the existence of imaginative literary works. It can be in a form of cultural heritage of Indonesia. Local knowledge is formed as a process of interaction between humans and their environment in order to meet various needs. The processes of formation of local knowledge is very dependent on natural resources and the environment and is influenced by the views, attitudes, and behavior of local people towards nature and the environment. Local knowledge is different in each region, and it contains a variety of specific norms and religious values. But, basically the process of local wisdom to walk in harmony with nature. This is in accordance with the opinion of Edmund Woga that substantively, local wisdom oriented towards 
balance and harmony of man, nature, and culture; sustainability and diversity of nature and culture; conservation of natural resources and cultural heritage; saving valuable resource economics; morality and spirituality [2].

Local knowledge can also be defined as a richness of local cultures containing life policies; outlook on life (way of life) that accommodates the policy (wisdom) and the wisdom of life. In Indonesia-which we know as the Archipelago-the local wisdom that applies not only locally on a particular culture or ethnicity, it can be said to be a cross-cultural or cross-ethnicity so as to form a national cultural values. For example, almost every local culture in the archipelago known local wisdom teaches mutual cooperation, tolerance, work ethic, and so on. In general, ethical and moral values contained in the local wisdom passed down through the generations, passed down from generation to generation through oral literature (among others in the form of sayings and proverbs, folklore), and manuscripts.

Although there are efforts of local knowledge inheritance from generation to generation, there is no guarantee that local knowledge would remain strong face of globalization that offers a lifestyle that increasingly pragmatic and consumptive. Factually, we can see how the local wisdom-laden policies and philosophies of life barely implemented in practice life is more pragmatic. Corruption is widespread in almost all levels are clear evidence of the denial of local wisdom that teaches "no pain, have fun and then"; "Thrifty rich base".

It has been stated in the literature that language and culture are intertwined [3]. Krampsch [4] for example stated that language expresses cultural reality embodies cultural reality and symbolizes cultural reality. Drawn from this cultural perspective, it can be said that the teaching of English in Indonesia is in the crossroads. On the one hand, English is naturally the language used to express, embody, and symbolize the culture of the native speakers of English. On the other hand, English is taught in the setting where the users are the speakers of other languages who have indigenous cultures different from those of native speakers of English. This condition raises an issue which is crucial in the teaching of English in the Indonesian context that is: which culture content should be taught to the learners of EFL?

Some of the authors emphasize the use of local culture in the teaching of EFL in Indonesia. This is because the EFL learners have been living in their own culture and, thus, using their own culture in the teaching of EFL will preserve their cultural identity. For example Octaberlina [5] stated that the use of local culture will promote local biodiversity. She added that local culture teaching enables the student to learn all language skills in English well. This is because, in her words, "the students will not have any difficulties since they are asked to describe about something that they know very well: that is their own culture. Octaberlina clearly supports earlier arguments expressed by Dalimunte and Tipka [6]. In their opinions, local culture teaching in English has a number of advantages, such as activating the students' background knowledge, making the students interested and motivated to talk about their own culture, and providing relevant materials for the needs of many Indonesian Students.

For a certain family, for example, dinner time is a time to share experiences or problems of what their have done on that day. In this occasion, caring and paying attention is quite needed and important. Through this chance in the dinner time the family meant to plant the habit of listening to what someone talking. So, by listening is also showing that we care. Listening could mean that we really listen to and pay attention what other people say. We don't just hear what they said. 
As what have been stated by Brown in his book Principles of Language Learning and Teaching, Transactional factors is needed in the process of language learning especially the social transaction which the second language learner is called upon to make constitute complex endeavors. Transaction is the process of reaching out beyond the self to others. The tools of language help to accomplish these feats. A variety of transactional variables comes to bear on second language learning: imitation, modeling, identification, empathy, extroversion, aggression, styles of communication, and others. Three of these variables, chosen for their relevance to a global understanding of second language acquisition, will be treated here: empathy, extroversion, and aggression [7].

\section{CHARACTER EDUCATION}

Character education refers to an education that teach the way of thinking and reacting to help the students in their live by cooperating with their family, society, and country [8].Character has various definition but basically they mean characteristics of a person which is shown through their speech, behavior, and thought. Character has become the basic on how the people react on their problem. Good characteristics is very needed by all people because it will directly influence their daily life. Character is also the main reason on how people see and describe us. This aspect is very important that before applying the job, for example, the psychology test is always given to check whether the person is suitable for the job or not [9].

Character education itself consist of two basic words, character and education. Education is basically taken from Latin word Educo or Educare which means training. Education itself has some different meanings from different terms but basically it refers to a system on how an adults directs, gives instruction to children, so, they can controlled in the matter of mentality and thinking process. While character refers to someone's self-identity. According to Kamus Besar Bahasa Indonesia, character is defined as characteristics, nature, and habit. It is similar to the explanation from Pusat Bahasa Depdiknas which can be defined as a heart, soul, characteristics, habit, and temper.

\section{GREAT LESSONS IN EMILY DICKINSON'S POEMS}

\section{Success is counted sweetest}

Success is counted sweetest

By those who ne'er succeed

The comprehend a nectar

Requires sorest need

Not one of all the purple host

Who took the flag today

Can tell the definition

So clear, of victory!

As he defeated dying 
On whose forbidden ear

The distant strains of triumph

Burst agonized and clear!

The poem was written in 1859 and published anonymously in 1864 . The poem uses the images of a victorious army and one dying warrior to suggest that only one who has suffered defeat can understand success. The theme is that doing without something makes a person appreciate its worth more than actually having it does[10]. The theme is revealed in the first two lines of the poem which read, "Success is counted sweetest / By those who ne'er succeed." In other words, no one appreciates the feeling of success better than a person who experiences failure. Those who do without in this poem do not do so by decision. They want what it is they do not have and, by not having it, want it even more. The poem goes on to say that to understand fully the satisfaction and joy of victory, one must suffer defeat and have to listen to the joyous cries of the winner. Dickinson sends a similar message in her poem "Water, Is Taught by Thirst," in which she alludes to the fact that only the truly thirsty appreciate all that water offers. This theme is a common one in everyday language. "Absence makes the heart grow fonder" is a popular saying with similar meaning. Emily Dickinson lived a fairly reclusive life and went unrecognized in her work. She knew that her life was one of denial, a state she apparently chose for herself. This lifestyle, however, made her more sensitive and more poetic.

This poem is not doubtfully, inspiring. Students are advised to always appreciate the failure. Failure is not totally bad phenomenon. It is exactly the right path given to human being to be able to reach the success. Much of what we know and understand has been learned through experience. Whether it was time spent in a classroom or having experiences out in the world, much of what we learn is accomplished through doing and interacting with others.

\section{GREAT LESSONS IN INDONESIAN WISE SAYINGS}

From some sayings and proverbs in culture of Indonesian people include Javanese people, there are three points about them that can be carried out in every single process of teaching and learning. They are as follows:

1. Bersakit-sakit dahulu bersenang senang kemudian. To feel sick first - To feel happy time then. This is the famous proverb of Indonesian that should be held and transferred to the next generation. This proverb means -hold the strong seriousness in achieving the ideals to achieve the ideals and can enjoy the pleasure or happiness. This proverb is suitable to be taught to the students because they are in the mission of achieving their ideal. This situation needs the big struggles. The teacher need to plant this kind of concept to the students in order that they will have high level of awareness and respect on the traditional values which virtually have the right advantages and values in live.

2. Experience is the best teacher. Everything that happened in our daily life actually already been destined and set by God. People should be careful in facing that. One important thing is that there is a lesson behind every event 
happened in our life. When a student ever undergoes the failure it is the way shown to reach the success. It is also possibly happened not only on students but also to the teacher. This is in line with expert's idea that "much of what we know and understand has been learned through experience. Whether it was time spent in a classroom or having experiences out in the world, much of what we learn is accomplished through doing and interacting with others". ${ }^{[11]}$

3. Madep, mantep, mantheng. This philosophy supports the notion that when pupils and teachers in the mission of doing something should be done to focus fixed on the object at hand, feel for it so do not be tempted to do something else, and have the resolve to finish until the work is completed. The teacher also need to plant this kind of concept to the students in order that they will have high level of awareness and respect on the traditional values which virtually have the right advantages and values in live. This habit will be often suitable especially on the stage of reading activity.

\section{CONCLUSION}

In the process of teaching and learning of English as a foreign language (EFL), learners are expected to express a culture with which they are barely familiar. Secondly, developing a new identity through exposure to the culture is likely affecting the learner's mental. Thus, it is important for the learners to know various kinds of their own culture in the country where they live. By having teaching and learning class of foreign language in an integrated way that relates to Indonesian culture, students are expected to be aware and have much knowledge about their own culture.

In reading imaginative literature works, students are hoped to be able to absorb every lesson provided. When they don't have the ability to catch the essential message, it is the duty of the teacher to assist them. The teacher is also expected to be a model or figure to apply the lesson of every imaginative literature product.

Related to the aim of study that is to reveal how imaginative literatures build students behavior, the results confirmed that reading imaginative literature is regarded as a special activity which serves to satisfy a wide variety of needs. The special students or a reader who is categorized as someone who is introverted and reluctant usually unable to participate fully in society and social surrounding. There is convincing evidence that through reading a person's life it can be a good material to be transformed. Also, for those who regard themselves as readers, reading is not only deemed a special activity but a crucial one. Their accounts reveal that the reading identity is not fixed but changes according to time and personal behaviour development.

To follow up the conclusion, some suggestions are proposed to the English students especially, teachers/lecturers, and other researchers. The students, teachers, 
and lecturers are suggested applying this idea independently not only in the classroom but also outside wherever and whenever they conducting teaching and learning process. Finally, for other researcher, this research hopefully can be an inspiration to do the next study and observations in the same field of research.

\section{REFERENCES}

[1] Rahardjo, Hendarto. 1988.Introduiction To English Literature.Surakarta.Universitas Sebelas Maret

[2] Woga .E. 2009. Misi, misiologi \& evalingesasi di Indonesia. [Internet]. [Cited 11 November 2011]. Can be downloaded from:http://books.google.co.id/books?id=TNSv00IumZAC\&printsec=frontcover\&dq=edmund+w oga\&hl=id

[3] Hinkel, E. 1999. Introduction: Culture in Research and Second Language Pedagogy. In E. Hinkel (Ed), Culture in Second Language Teaching and Learning (pp. 1-7).Cambridge University Press.

[4] Kramsch, C.1998. Language and Culture. Oxford:Oxford University Press.

[5] Octaberlina, L. R. 2011. Promoting Local Culture through Creative Writing is Like Buy One Get One (Read: Three) Free.'Power-points hands out presented in the Asia Creative Writing Conference, Jember, 31 March \& 1 April

[6] Dalimunte \& Tipka, B. 2004. "Using Local Culture as Content in EFL Courses: Benefits and Limitation," presented at the 52 ${ }^{\text {nd }}$ TEFLIN International Conference, Palembang, 7-9 December, 2004.

[7] Brown, D.2007. Principles of Language Learning and Teaching. Pearson Education,Inc.

[8] Kanzunuddin, M. 2011. Peran Sastra Dalam Pendidikan Karakter. Fakultas Keguruan Dan Ilmu Pendidikan Universitas Muria Kudus.

[9] Purwitasari, Dian.2015 .The Local Wisdom Values in Indonesian Local Folklores and How It Contributes to Character Education. Paper presented in the $2^{\text {nd }}$ forum on linguistics and literature (FOLITER), Malang, September

[10] http: // en. Wikipedia.org/wiki/Success is Counted The Sweetest modified on 24 july at 17.57

[11] Huhman,Heathert R. Nov,27,2013. Four Reasons Experience Is The Best Teacher. 